\title{
Design Thinking Konsep Budget Phone sebagai Solusi dalam Berteknologi Inspirasi Nabi Muhammad Saw.
}

\author{
Fajar Khaswara \\ Jurusan Studi Agama-Agama, Fakultas Ushuluddin \\ UIN Sunan Gunung Djati Bandung, Indonesia \\ fkhaswara@gmail.com
}

\begin{abstract}
This study aims to discuss the inspiration of the Prophet's hadith. in the use and utilization of technology. This research method is qualitative through literature study and field studies with the hadith design thinking approach, the use of devices in usefulness. The results and discussion include the use of the device, the Prophet Muhammad SAW. examples in technology life, and ideas for problem solutions from the inspiration of the Prophet's hadith. This research concludes that the hadith of the Prophet Muhammad has inspirational messages in making good use of technology which can lead to positive things.
\end{abstract}

Keywords: Design Thinking; Gadget; Hadith.

\begin{abstract}
Abstrak
Penelitian ini bertujuan membahas inspirasi hadis Nabi Saw. dalam penggunaan dan pemanfaatan teknologi. Metode penelitian ini bersifat kualitatif melalui studi pustaka dan studi lapangan dengan pendekatan design thinking hadis penggunaan gawai dalam kebermanfaatan. Hasil dan pembahasan ini meliputi penggunaan gawai, Nabi Muhammad Saw. teladan dalam kehidupan berteknologi, dan ide solusi masalah dari inspirasi hadis Nabi. Penelitian ini menyimpulkan bahwa hadis Nabi Saw. memiliki pesan-pesan inspiratif dalam memanfaatkan teknologi dengan baik sehingga menimbulkan hal positif.
\end{abstract}

Kata kunci: Design Thinking, Gawai, Hadis Nabi Saw.

\section{Pendahuluan}

Istilah "gawai" merujuk pada perangkat elektronik portabel yang bisa dikategorikan ke dalam beberapa benda seperti telepon seluler, pemutar musik, konsol gim, dan segala perangkat nirkabel lainnya (Gupta, N. et al., 
2013). Inovasi teknologi saat ini begitu pesat. Banyak perubahan terjadi, misalnya saja gawai. Perangkat ini merupakan teknologi yang tidak bisa lepas dari kehidupan manusia. Setiap kegiatan yang ada pasti membutuhkan gawai, terlebih lagi pada masa pandemi seperti sekarang. Berdasarkan data dari Badan Pusat Statistik menunjukan bahwa pelanggan telepon selular mencapai 313,43 juta pelanggan pada tahun 2018 (Badan Pusat Statistik, 2019).

Bagi setiap muslim, baginda Nabi Muhammad Saw. merupakan figur teladan dalam segala kehidupan. Kegiatan yang dilakukan sehari-hari tentunya harus efisien dan bermanfaat bagi sekitar atau diri sendiri. Seperti tidak membuang-buang waktu dan tidak melakukan pemborosan. Pada masa pandemi seperti saat ini, banyak hal yang bisa dimanfaatkan, contohnya adalah gawai. Benda-benda ini bisa digunakan dalam melakukan hal yang luar biasa seperti ponsel. Perangkat yang telah menjadi multi-fungsi ini bisa menjadi kamera, radio, teknologi nirkabel, dan sebagainya (Lee, 2005). Manfaat dari multi-fungsi tersebut bisa digunakan untuk kegiatan seperti yang telah disebutkan.

Berdasarkan paparan di atas, penulis berusaha menyusun rumus penelitian, yaitu rumusan masalah, pertanyaan penelitian, dan tujuan penelitian (Darmalaksana, 2020a). Rumusan masalah dalam penelitian ini adalah inspirasi hadis Nabi Muhammad Saw. dalam memanfaatkan benda di sekitar. Pertanyaan penelitian ini adalah bagaimana hadis bisa menginspirasi manusia dalam pengembangan gawai. Tujuan penelitian ini adalah untuk membahas inspirasi Nabi Muhammad dalam efisiensi gawai dan. Penelitian ini berfokus kepada konsep budget phone yang telah dikembangkan dalam beberapa perangkat gawai.

\section{Metode Penelitian}

Metode penelitian ini bersifat kualitatif dengan studi pustaka dan studi lapangan (Darmalaksana, 2020b). Sedangkan analisis dalam penelitian ini digunakan pendekatan design thinking (Darmalaksana, 2019). Adapun prosedur pendekatan design thinking (Darmalaksana, 2020c) ditunjukkan pada gambar 1 .

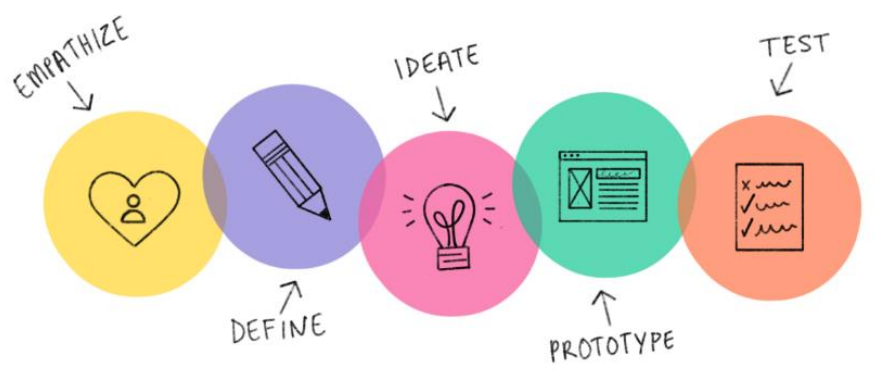

Gambar 1 Prosedur Design Thinking 
Prosedur design thinking pada Gambar 1 meliputi fase empathize, define, ideate, prototype, dan test (Henriksen et al., 2017).

1. Fase empathize (empati) digunakan untuk memahami masalah. Empati dilakukan melalui proses mengamati, keterlibatan melalui percakapan, dan wawancara secara mendalam. Tujuan fase ini adalah memahami masalah secara seksama (Darmalaksana, 2020c; Steinke et al., 2018).

2. Fase define (mendefinisikan) masalah untuk kejelasan masalah. Peneliti menerapkan kekuatan berpikir untuk memahami masalah. Setelah masalah dipahami dengan jelas, peneliti dapat pindah ke tahap berikutnya untuk menghasilkan ide mengatasi masalah. Fase definisi diakhiri dengan ditetapkan secara jelas tentang ruang lingkup masalah (Darmalaksana, 2020c; Steinke et al., 2018).

3. Fase ideate (menghasilkan ide-ide) untuk solusi masalah yang didefinisikan sebelumnya. Peneliti memungkinkan menggunakan logika secara kritis, kreatif, dan inovatif. Fase ideating mencakup peta konsep, kerangka berpikir, dan desain prototipe. Khususnya, prototipe dengan pandangan baru sebagai solusi (Darmalaksana, 2020c; Steinke et al., 2018).

4. Fase prototype (membuat prototipe) dari ide inovasi baru hingga produk terwujud. Semakin realistis ide prototipe, maka semakin baik untuk diwujudkan. Peneliti memungkinkan mengenali kekurangan prototipe untuk desain yang lebih inovatif, sehingga mereka dapat mengulangi pembuatan produk yang lebih baik (Darmalaksana, 2020c; Steinke et al., 2018).

5. Fase test (pengujian) sebagai umpan balik (feedback) terhadap prototipe yang didesain sebelumnya. Pengujian memungkinkan mengulangi proses empati secara lebih diharapkan. Umpan balik dari fase ini akan membantu penyempurnaan prototipe, hingga dipastikan bahwa masalah ditangani dengan tepat (Darmalaksana, 2020c; Steinke et al., 2018).

\section{Hasil dan Pembahasan}

Hasil dan pembahasan melalui pendekatan design thinking di bawah ini.

\section{Penggunaan Gawai}


Gawai adalah peranti elektronik dengan fungsi praktis. Istilah gawai sendiri lebih umum digunakan pada perangkat seperti telepon cerdas. Pada masa pandemi seperti ini penggunaan gawai terus meningkat dikarenakan banyak kegiatan yang dialihkan menjadi daring. Banyak kegiatan yang tadinya dilakukan secara luring harus beradaptasi terhadap pandemi saat ini. Hal ini tentu menjadi masalah bagi mereka yang kurang memahami teknologi. Masalah lain juga timbul seperti jangka waktu penggunaan gawai yang meningkat dan menyebabkan kecanduan bagi penggunanya.

Pendekatan design thinking diharapkan dapat memecahkan masalahmasalah yang timbul pada saat ini, termasuk memperluas akses masyarakat terhadap teknologi dan mengedukasi mereka bagaimana penggunaan gawai secara baik dan bermanfaat. Pendekatan ini menawarkan empati, mendudukan masalah secara jelas, dan mencari ideide kreatif (Steinke et al., 2018). Meskipun pada saat ini masih banyak masyarakat sulit mengakses dan memanfaatkan perkembangan teknologi dengan baik.

Masalah utama dalam penggunaan gawai ini adalah persoalan kurangnya akses dan di satu sisi ada yang kecanduan, terutama dalam kalangan anak-anak yang semakin individualis (Warisyah, 2019). Penelitian ini bertujuan untuk mendapatkan empati atas masalah-masalah tersebut untuk mencari ide yang kreatif, inovatif dan dapat mencari solusi berdasarkan inspirasi hadis Nabi Saw.

\section{Nabi Muhammad Saw. Teladan dalam Kehidupan Berteknologi}

Nabi Muhammad Saw. merupakan pribadi yang wajib diteladani bagi setiap muslim baik setiap perkataannya maupun perbuatannya. Secara bahasa, hadis berarti al-jadid (sesuatu yang baru) yang merupakan lawan kata dari al-qadim (seuatu yang lama). Istilah hadis juga sering disebut sebagai al-khabar (berita), yaitu suatu percakapan atau pembicaraan yang pindah dari satu orang ke orang lainnya. Istilah jamaknya adalah al-ahadits (Al-Khatib, 1989; Al-Qasimi, 1979; Al-Sabbag, 1972). Kapasitas Nabi Muhammad Saw. dalam kehidupan tentu tidak diragukan lagi baik itu sebagai pemimpin, kepala rumah tangga, dan segala ucapan dan perbuatannya merupakan bentuk implementasi ajaran Islam.

Banyak hadis yang bisa sandarkan kepada kehidupan berteknologi baik itu dalam pemanfaatan barang seperti gawai dan sebagainya. Jika melihat konteksnya seperti pemanfaatan teknologi pada era modern ini, rasanya sulit untuk mencari hadis yang berkaitan langsung. Alternatif lainnya adalah menggunakan hadis yang walaupun secara harfiah tidak berkenaan langsung. Nabi Muhammad Saw. bersabda: 


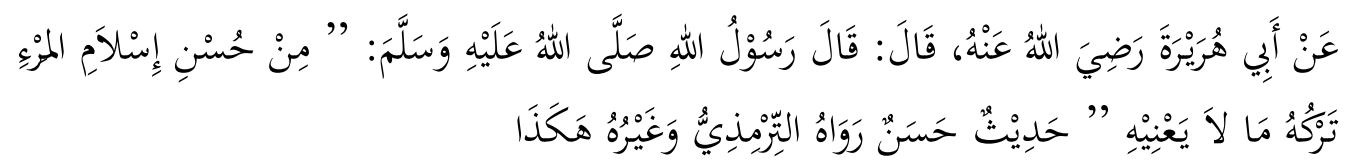

Dari Abu Hurairah radhiallahu 'anhu, dia berkata: "Rasulullah salallahu 'alaihi wa sallam pernah bersabda: "Sebagian tanda dari baiknya keislaman seseorang ialah ia meninggalkan sesuatu yang tidak berguna baginya" (HR. Tirmidzi No. 2318).

Hadis di atas bernilai hasan. Hadisnya diriwayatkan oleh Imam atTirmidzi dalam kitabnya yang berjudul az-Zuhd di bab Maa Jaa-a fiiman Takallama fiimaa Laa Ya'niihi. Seperti yang telah dijelaskan, hadis tadi tidak berkaitan secara langsung dengan pemanfaatan teknologi. Namun, hadis tersebut dapat menjadi inspirasi umat muslim dalam kehidupan berteknologi khususnya dalam memanfaatkan gawai sebaik mungkin. Nabi Muhammad Saw. tetap bisa menjadi inspirasi setiap muslim untuk melakukan hal yang bermanfaat dan meninggalkan sekiranya yang sama sekali tidak bermanfaat.

\section{Ide solusi masalah dari inspirasi hadis Nabi}

Pengembangan gawai dengan harga murah atau yang disebut juga sebagai budget phone merupakan inovasi yang kreatif. Hal ini tentu bisa mengatasi masyarakat kelas bawah dalam akses terhadap gawai. Walaupun banyak fitur yang dipangkas. Perangkat gawai yang mahal memang mempunyai banyak fitur yang lengkap namun beberapa fitur tersebut terkesan tidak dibutuhkan. Merujuk pada hadis Nabi untuk meninggalkan hal-hal yang tidak bermanfaat, budget phone ini merupakan hal alternatif yang bisa diakses masyarakat kelas bawah dalam hal teknologi. Konsep budget phone ini setidaknya telah membantu masyarakat kelas bawah dengan menyediakan gawai dengan harga murah namun dengan memangkas beberapa hal yang sekiranya tidak perlu. Sistem operasi merupakan salah satu hal yang dipangkas menjadi lebih simpel dalam budget phone. Android Go merupakan bentuk dari sistem operasi yang dipangkas dari versi original Android. Pertama kali dibuat sekitar tahun 2017 (Morrill, 2008), Android versi Oreo merupakan versi yang pertama mendapatkan modifikasi menjadi lebih ringan. Hal ini ditujukan untuk gawai dengan besaran RAM 2 GB atau kurang. Beberapa vendor ternama seperti Samsung dan Nokia sudah lebih dulu menerapkan hal ini dalam perangkat yang mereka pasarkan.

Masalah selanjutnya dalam pemanfaatan gawai ini adalah kecanduan terhadap gawai. Beberapa penelitian tentang penggunaan gawai menghasilkan masalah seperti depresi, kesepian, kurangnya kontrol 
impuls, kenyamanan sosial, dan beberapa gangguan lain yang bisa menimbulkan efek kronis bagi penggunanya (Suhana, 2017). Konsep budget phone ini setidaknya telah berperan dalam mengatasi kecanduan gawai, seperti kapasitas penyimpanan yang terbatas sehingga mengurangi rasa ingin bermain gim dan berlama-lama dalam menggunakan gawai. Hal ini tentu selaras dengan hadis Nabi untuk meninggalkan hal yang tidak bermanfaat.

Berdasarkan design thinking, vendor gawai ini harus memperhatikan gawai yang mereka buat dalam berbagai ujicoba (Steinke et al., 2018). Pertama, penelitian untuk mencari potensi pasar dengan menguji semua kelas masyarakat. Kedua, memilih strategi pemasaran yang efektif dalam berbagai konteks. Ketiga, produk diperkenalkan secara kreatif tergantung apa yang dibutuhkan pasar. Keempat, promosi yang dilakukan perusahaan harus menerapkan tata cara yang tepat sesuai etika yang berlaku dalam masyarakat. Kelima, uji coba secara berkala, sehingga menemukan prototipe yang tepat, sistem pembagian yang baik, dan analisis keuntungan yang didapat. Lima tahap ini merupakan solusi dari design thinking (Steinke et al., 2018).

Hadis Nabi tetap relevan hingga saat ini dalam berbagai lini kehidupan. Bagaimanapun juga konsep budget phone yang berkembang pada saat ini merupakan peluang untuk membentuk manusia yang sehat secara rohani, baik itu membuat manusia untuk mengakses perkembangan teknologi dan mencegah dari kecanduan terhadap gawai. Jika pengembangan dilakukan lebih lanjut tentu hal ini berpotensi membuka banyak peluang bagi masyarakat dengan ekonomi rendah bisa mengakses gawai dengan mudah.

\section{Kesimpulan}

Hadis memberikan inspirasi manusia dalam kehidupan berteknologi menurut design thinking melalui beberapa fase seperti empathize, define, ideate, prototype, dan test. Nabi Muhammad Saw. merupakan teladan bagi umat manusia, dengan bukti-bukti keteladanannya bisa membimbing manusia modern menjadi lebih baik lagi. Konsep budget phone ini setidaknya telah membantu mereka yang kesulitan terhadap akses gawai dan mengendalikan diri dari kecanduan gawai. Melalui design thinking, muncul ide-ide kreatif, inovatif, dan solutif. Penelitian ini diharapkan mampu menginspirasi dan bermanfaat untuk berbagai para vendor gawai dan masyarakat. Penelitian ini terbatas pada bahasan "budget phone" sehingga dibutuhkan penelitian lebih lanjut untuk meneliti hal ini. Penelitian ini juga merekomendasikan untuk melakukan pengujian lagi dalam upaya untuk menemukan prototype yang lebih tepat. 


\section{Referensi}

Al-Khatib, M. A. (1989). Usul al-Hadith, Ulumuh wa Mustalahuh. Dar alFikr.

Al-Qasimi, M. J. al-D. (1979). Qawa'id at-Tahdith min Fununi Mustalah alHadith. Dar al-Kurub al-Ilmiah.

Al-Sabbag, M. (1972). al-Hadith al-Nabawi; Mustalahuh Balagatuh Ulumuh Kutubuh. Manshurat al-Maktab al-Islami.

Badan Pusat Statistik. (2019). Statistik Telekomunikasi Indonesia 2018 (S. D. S. K. dan T. Informasi (ed.)). Badan Pusat Statistik.

Darmalaksana, W. (2019). Paper Template Design Thinking Methods for Learning Hadith. Fakultas Ushuluddin UIN Bandung.

Darmalaksana, W. (2020a). Formula Penelitian Pengalaman Kelas Menulis. Jurnal Kelas Menulis UIN Sunan Gunung Djati Bandung.

Darmalaksana, W. (2020b). Metode Penelitian Kualitatif Studi Pustaka dan Studi Lapangan. Pre-Print Digital Library UIN Sunan Gunung Djati Bandung.

Darmalaksana, W. (2020c). Template Penulisan Artikel Hadis dengan Pendekatan Design Thinking. Pre-Prin Digital Library UIN Sunan Gunung Djati Bandung, 1(1), 1-7.

Gupta, N., Krishnamurthy, V., Majhi, J., \& Gupta, S. (2013). Gadget Dependency among Medical College Students in Delhi. Indian Journal of Community Health, 25(4), 362.

Henriksen, D., Richardson, C., \& Mehta, R. (2017). Design thinking: A creative approach to educational problems of practice. Thinking Skills and Creativity, 26, 140-153. https://doi.org/10.1016/j.tsc.2017.10.001

Lee, D.-H. (2005). Women's Creation of Camera Phone Culture. The Fibreculture Journal, 6.

Morrill, D. (2008). Announcing the Android 1.0 SDK, release 1. Android Developers Blog.

Steinke, G. H., Al-Deen, M. S., \& LaBrie, R. C. (2018). Innovating information system development methodologies with design thinking. Proceedings of the 5th Conference in Innovations in IT.

Suhana, M. (2017). Influence of Gadget Usage on Children's SocialEmotional Development. Advances in Social Science, Education and Humanities Research (ASSEHR), 169, 234-237.

Warisyah, Y. (2019). Pentingnya "Pendampingan Dialogis" Orang Tua dalam Penggunaan Gadget pada Anak Usia Dini. Inovasi Pembelajaran Untuk Pendidikan Berkemajuan, 130-138. 


\section{Ucapan Terima Kasih}

Alhamdulillah, puji syukur kepada Allah Swt. dan terima kasih kepada bapak Dr. Wahyudin Darmalaksana, M. Ag., selaku dosen mata kuliah Hadis, kepada kedua orang tua saya, kerabat dekat saya, dan kepada teman-teman yang telah memberikan dukungan dalam proses penulisan artikel ini. 